\title{
SENTIMENTAL JOURNAL: THE DIARY OF MARGARET MILLER DAVIDSON
}

\author{
EDITED BY WALTER HARDING
}

An Instructor in English at Rutgers, Walter Harding is now engaged in cditing Thoreau's correspondence.

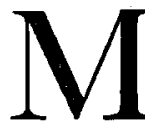

ARGARET MILLER DAVIDSON was once one of the best-known poets in America. When she died, no less a person than Washington Irving felt it his duty to write her biography and edit her collected poetry. ${ }^{1}$ Now she is little more than a name to students of American literature.

Miss Davidson was born in Plattsburg, New York, on March 26, I823, the youngest daughter of Dr. Oliver and Mrs. Margaret Davidson. Her mother achieved some fame in her own right as a contributor to the London Quarterly Review and in I 843 published a volume of her own writings with a preface by the popular novelist Miss Catherine Sedgwick. ${ }^{2}$ An older sister, Lucretia Maria Davidson, who died in I 825 at the age of sixteen, achieved a posthumous fame through the publication of her poems with an introduction by Samuel F. B. Morse, the painter and inventor. ${ }^{3}$ So great was her renown that William Cullen Bryant dedicated an elegy to her on her death.

In fragile health from birth, Margaret was tutored at home by her mother. At the age of six she displayed her precocity by reading the works of Milton, Byron, Scott, Thomson, and Cowper. At the age of seven she was studying grammar, geography, history, and rhetoric. At eight she was composing poetry. When she died at the tender age of fifteen, she left behind more than two hundred pages of poetry found worthy of publication.

Margaret spent the winter of I 832-3 visiting a married sister at Caldwells Manor, Canada. There she contracted scarlet fever and for weeks was desperately ill. When she recovered, her family brought her home, and the mother and daughter continued on to New York City. Her diary of that journey, owned by her great-niece

\footnotetext{
${ }^{1}$ Washington Irving. Biography and Poetical Remains of the Late Margaret Miller Davidson. (Philadelphia: Lea and Blanchard, 1841).

2 Selections from the Writings of Mrs. Margaret M. Davidson. (Philadelphia: Lea and Blanchard, 1843 ).

${ }^{3} \mathrm{Amir}$ Khan, and Other Poems: the Remains of Lucretia Maria Davidson. (New York: Carvill, 1829).
} 
Miss Catherine L. Davidson of New Brunswick, New Jersey, is now on loan in the Rutgers University Library. Written when she was but ten years old, it covers twenty-six manuscript pages in a little marbled notebook. The following verbatim transcription [with some omissions] furnishes a perfect example of the sentimental school of writing, but it also gives a remarkably vivid picture of the times.

Left Caldwells Manor on friday May 31 st 1833 , in company with my Father my brother and sister Townsend, a young lady, and my little nephew, my mother and myself made up the party; we were obliged to ride seven miles before we came to the river which we were to cross, it was a fine day and as we rode slow, that we might not fatigue mama, (who is quite feeble,) I had an opportunity to admire what beauties were presented by the varied landscape; altho' no grand or sublime scenery presented itself, yet the verdant meadows and the shady pines, excited an interest in my mind, for I thought I might now be viewing them for the last time, or at least that I might not revisit them until myself, and those I best loved there, were greatly changed, rendered good or evil, beautiful or deformed by time or age-... [With some difficulty they started across Lake Champlain in a seriously overloaded boat.] ...

At last we drew near the American Fort, it was a majestic ruin, it is so defaced that you cannot distinguish its original form, broken windows delapidated portholes, and sometimes the remains of a ruined entrance, yet to me the sight was deeply interesting, and I forgot the cold chill wind, the swelling waves, and all else which had occupied my mind while gazing at this memento of my countrys victory-it stood there silent and solitary. I could not but compare it to a noble mind in ruins, majestic in its fall, grandeur pervading every fragment, there seemed to dwell some haughty spirit there, which defied the power of man, yet crumbling beneath his influence, we passed it, and to our great Joy, soon landed on the opposite Shore; but lo! the Steam boat was in sight, and we had two miles to ride, to reach the Wharf where we were to embark, the gentlemen with our young female friend had designed to walk, mama Sister and myself were to proceed in the gig which was to be led, as we had a gay horse, but this arrangement would delay us too long and we feared we would miss the boat, therefore my father, Charlotte, my little nephew, and myself, were huddled on the top of the lumber waggon which was already filled with baggage sufficient for two horses to draw over the rough and dangerous roads we were obliged to pass, it was a narrow strip of land barely wide enough for our carriages to pass, surrounded on both sides by deep water, in some places the road was entirely worn away by the rushing of the waves, and a few shattered plank thrown across the breach was dignified by the name of bridge; in one place a man had kindled a fire and was boiling a kettle of Pot ash, and the horses were put to their Speed lest the fire or the heat arising from it might frighten them; at length we reached Champlain, hurried into the boat, and in three hours were landed at our own little Village of Plattsburgh, the place of my birth, endeared to me by a thousand tender recollections - here we spent a few days delightfully 


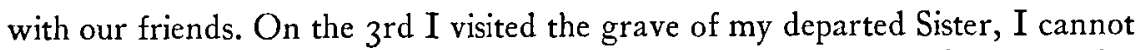
describe my sensations while bending over the turf which covered the remains of so much worth and genius, innocence and beauty, here within this dark, damp, and narrow grave, she reposes in silent unconciousness, this simple monument raised by the affection of a mourning father is all which distinguishes her from the common mass of mouldering clay by which her remains are surrounded. I plucked a sprig of sweet briar from the grave to present to my friend Mrs Youle ... [On the 5th, they took an overnight boat to Whitehall.] . . we then entered the stage which was to convey us to Saratoga Springs, our drive was not unpleasant although the stage was so crowded, that papa and two other gentlemen were obliged to take seats on the top of the Coach we passed the beautiful Hudson, and oh, how sweet was the scene which then presented itself, the quiet shores o'erhung with trees, whose foliage glistened in the Sunbeams, the peaceful waves on one side, and little Islands smilling between, while on the other, the dashing waterfall, which sparkled like so many gems, all reminded me of my own dear Saranac - the waterfall the bridge, the Islands, the river, all forcibly recalled to my mind the scenes I love to view so well, we arrived at the Springs at about 8 o'Clock in the evening, after having enjoyed in the highest degree the beautiful and varied scenes which presented themselves to the eye, mountain rising above mountain plain succeeding plain and all not in my opinion to be equaled except in sailing from Albany to New York on the North River-my dear Mother was taken from the Coach nearly fainting with fatigue and debility - our first care was [to] procure a quiet room and refreshment for [her], and after a good nights rest she awoke much recruited in strength and spirits-June 7 th. My mother is unable to go down-I went down to breakfast with my father, and after the ceremonies of that repast were over, I had an opportunity of examining and making my observations on this stately edifice-Union Hall is kept by a Mr. Putnam a descendant of old Genl Putnam-a large piazza in front, ornamented with Shrubbery gives it quite a rural appearance, the entrance is into a spacious Hall which opens with folding doors into a Splendid Saloon which is ornamented with elegant paintings -in the centre is suspended a large lamp which when lighted gives it a most brilliant appearance, a centre table contains various implements of amusement, and exercise for the entertainment of the votaries of pleasure, who constantly flock to this place; two pair of folding doors opens from the Saloon, one pair admits you to the drawing, the other to the dining room-the former is a very elegant apartment splendidly furnished, the walls are ornamented with beautiful engravings representing various scenes in Ivanhoe--one representing the young hero as offering himself as a Champion to the suffering Rebecca; the lady Rowena crowning the magnanimous Ivanhoe with the dear bought wreath of victory, Rebecca in the prison, and others, equally interesting - a sofa stands on one side the door, a piano, on the other, on the East Side of the room-a glass door, opens into a handsomely decorated garden Lichens, pinks, lillies, geraneums, and other choice flowers tastefully arranged in rich profusion ornament the Spot, on the mantle piece stands a flower pot filled with these toys of nature and a large mirror reflects the splendor of every object. . . 8 th this day 
being the Sabbath, I spent chiefly in my mothers room; I rose and drank the water breakfasted with a good appetite and while in the drawing room attached myself chiefly to a Mrs Hart, a lady from Utica who treats me with much attention, and I am become quite attached to her, with a few exceptions there is no very interesting Company here but my time passes very pleasantly-After dinner papa went with me to the rock Spring. Oh! what a curiosity it is, from a fissure in a large rock Springs the water of health, when I viewed it [it] reminded me of the refreshing fountain which flowed in the wilderness, to refresh the wearied, and half fainting Sons of Israel, the chosen of heaven; I intend to attempt a sketch of this rock, that my friends in New York may see it; we returned and drank tea, and went to church with Papa, heard a good plain practical Sermon, from the words, "What shall I do to be saved" returned home and retired to rest, and soon lost all recollection of the events of the day in refreshing slumber Monday gth arose breakfasted, and walked with father to the library, found the day uncomfortably Cold, put on a winter dress, Spent the remainder of the day in mama's room, reading conversing and drawing, in the evening my dear father gave me a most deligh [ $t$ ] ful surprise by presenting me with a full and complete copy of Byrons works which contains a sketch of his life by W Lake all hansomely bound in one volume, likewise Lockharts Burns-this valuable addition to my little library so delighted me, that I was almost beside myself. ... [She amused herself in reading and walking with

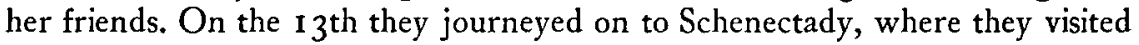
relatives and toured an institution for the blind.] ...

On the 25th of June I saw, and shook hands with the famous Black Hawk the Indian Chief, the enemy of our nation, who has massacred our patriots, murdered our Women and helpless children. Why is he treated with so much attention by those whom he has injured? it cannot surely arise from benevolence, it must be policy but I cannot understand it; his son, the Prophet, and others who accompanied him, interested me more than the Chief himself, his son no doubt was a fine specimen of Indian beauty, he had a high brow piercing black eyes, long black hair, which hung down upon his back, and upon the whole I think he was well suited to captivate an Indian Maiden; The Prophet we found surveying himself in a looking glass undoubtedly wishing to shew himself to the best advantage to the fair assembly before him, the rest were dozing on a sofa, but they were waked sufficiently to Shake hands with us and others who had enough courage, to approach so near them-Black Hawk himself was less prepossessing in his manners and features, than the rest though none were particularly beautiful, all but the Chief wore blankets ear rings necklaces and ribbons of every colour pined to their backs, which made them look very singular-we soon returned and if I remember, dreamed of them the following night.

On the fourth of July brother Morris and myself visited the Museum, that we might have a better opportunity of seeing the parade, $t$ 'was perfectly new to me, and I was perfectly delighted, as the soldiers marched along their way I thought of my dear brother Levi who is a Cadet at West Point, and I could 
not but wish I might one day see him defending his Country with an arm strengthened by gratitude for its kindness to him, and love for his own meritst'was a grand sight to see them pass along, the officers on their milk white steeds, the floating banners and the martial step with which they pursued their Course, all was new to me and I enjoyed myself more than I had anticipated....

A few days since Uncle Miller Cousin Margaret Youle, and her sweet little boy, George, made up a party to Hoboken, one of the most delightful places I ever saw, 'tis opposite New York on the bank of the North River, just far enough from the City to render the view delightful. We wandered around its beautiful and Shady walks until Sun set, sometimes fancying I saw a Hermits Cavern, sometimes a Shady Grove where lovers might sit and sigh, at others a leafy bank where some fair maiden might recline in rural beauty, on the softest couch that Nature ever yielded, I have been told that a Monument was once erected to the memory of the great General Hamilton, who fell in a duel by the hand of the infamous Burr, near the spot which I visited. I regret I did not know it at the time, I should have felt a melancholy pleasure in gazing at the spot where so celebrated a man yielded his breath, and have considered it as quite an era in my life; How lamentable the reflection that so great a man, should have fallen a victim to those false notions of honor which have proved so fatal to many of the brightest ornaments of Society! how infamous the conduct of his cowardly antagonist, view the contrast, while Hamilton with noble courage refrained from injuring him, Burr, with one murderous blow, destroyed the life so dear to his country \& family.

I have never until yesterday seen the Ocean, and I have always had a great desire to see this vast expanse, my dear friends have gratified me, with them I have visited Coney Island seen, and tasted the waves, of the great Atlantic! it Spread before my youthful eye, a waste of waters, its roaring sound seemed music to my ear, the dashing foam curling around the brow of every wave, seemed a majestic Coronet placed there by the hand of the Almighty, to render them more grand and impressive, several Ships were seen coming and going returning and departing from their homes, what must be the feelings of their passengers! perhaps they have husbands, wives, children, and friends, perhaps some aged mother will soon be clasped in the warm embraces of her darling child, perhaps she is now watching the slow progress of the vessel, which conveys her all, her dearest from her, I know not, but fancy will pursue its own course, whether it pierce the secrets of the watery deep, soar on her airy pinions to the aerial sky or dare to gaze 'neath the dark curtains of futurity. I cannot control it, t'will fly on regardless of aught else! what thoughts then pressed upon my mind, 'twere impossible to describe, did the same wave that washed the sands I stood on, lave the banks beyond the waters plain before me? Oh! England, has some mighty Spirit wafted o'er the wave those feeble barks who in their little space contain so many souls? did not the Great $I A M$ watch o'er thee, couldst thou brave the perils of the sea and cross in safety to yon distant shore? bright world beyond my view, and dost thou equal fair America? I 
know not, Empires fall, Kings die, nature changes, but thou great Ocean art unchangeable! "Time writes no wrinkles on Thine azure brow." . . [On the evening of the I 8 th she visited an exhibition of fireworks.] ...

On the 3 Ist July the celebrated Washington Irving honored us with a call, I have seen this great man, the pride of his country, the ornament of society, and the author of Knickerbocker, the Sketch Book, Alhambra, and the life of Columbus, imagination cannot paint my feelings at this moment. I have met, I have for a few short blissful moments breathed the same air with him; I felt a sensation of awe, reverence, and admiration, steal over my mind, as I gazed on the fine lineaments of his noble face, his piercing eye, his jet black hair his broad high brow excited feelings, I am unable to describe; in every feature, I thought I could trace some amiable quality or some trait of brilliant genius, the hair which clustered around his forehead seemed to my enraptured eyes, a wreath of laurel bound around it by the "genius of America" some guardian muse seemed hovering near to inspire his heart with poetic enthusiasm; my mind was strongly excited long after he bade us farewell, and the effect produced upon it, will never be erased. ${ }^{4}$

The diary closes with a few sentences on a trip to Staten Island. Margaret's health was still precarious. In vain her family moved from town to town in search of a climate more favorable to her. But she had contracted pulmonary tuberculosis and slowly faded away. She died on November 25, I 838, at the age of fifteen years and eight months, and was buried in the family plot at Saratoga, New York. The publication of her poetry by Irving in I 84I brought her widespread fame. She and her sister were looked upon as American Chattertons, as vivid proof of the latent genius in childhood. But a new generation tired of sentimentalism, and the Davidson sisters were forgotten. Now, however, we may find in this diary a key to the literary tastes of a century ago.

\footnotetext{
${ }^{4}$ Irving gave his own account of this visit. He was discussing Lucretia's works with her mother when, "I observed a young girl, apparently not more than eleven years of age, moving quietly about her; occasionally arranging a pillow, and at the same time listening earnestly to our conversation. There was an intellectual beauty about this child that struck me; and that was heightened by a blushing diffidence when Mrs. Davidson presented her to me as her daughter Margaret." $O p$. cit., p. Io.
} 